\title{
Implementation of Guided Inquiries to Increase Science Learning Outcomes about Changes in Objectives
}

\section{Arbangatun Fitriana}

Universitas Sebelas Maret

arbangatunf@gmail.com

\section{Article History}

received 30/4/2021

\begin{abstract}
The objective of this research is to improve science learning outcomes about changes in objective through the implementation of guided inquiry. This research is a collaborative Classroom Action Research (CAR) conducted within two cycles. Subjects of the research were fifth grade students. Techniques of collecting data were observation, interview, documentation, and test. Validity of data in this research was analyzed using triangulation of sources and triangulation of technique. Data analysis consists of data reduction, data display, and drawing conclusion. In the first cycle, the students' completeness reached $68.42 \%$. In the second cycle it reached $89.47 \%$. The results of this research show that the implementation of guided inquiry learning model can improve science learning outcomes about changes in objective of students in grade V SDN 1 Karangsari academic year 2020/2021.
\end{abstract}

Keywords: Guided Inquiry, Science Learning

\section{Abstrak}

Tujuan penelitian ini yaitu untuk meningkatkan hasil belajar IPA tentang perubahan wujud melalui penerapan model pembelajaran inkuiri terbimbing. Penelitian ini merupakan penelitian tindakan kelas (PTK) yang dilaksanakan dalam tiga siklus. Subjek penelitian ini adalah siswa kelas $\mathrm{V}$. Teknik pengumpulan data menggunakan observasi, wawancara, dan tes. Validitas data menggunakan triangulasi teknik dan sumber. Analisis data meliputi reduksi data, penyajian data, dan kesimpulan. Pada siklus I ketuntasan peserta didik mencapai $68,42 \%$. Sedangkan pada siklus II mencapi $89,47 \%$. Hasil penelitian ini menunjukkan bahwa penerapan model pembelajaran inkuiri terbimbing dapat meningkatkan hasil belajar IPA tentang perubahan wujud pada peserta didik kelas V SDN 1 Karangsari Tahun Pelajaran 2020/2021.

Kata kunci: Inkuiri Terbimbing, IPA 


\section{PENDAHULUAN}

Berdasarkan Surat Edaran Nomor 36962 tertanggal 17 Maret 2020 tentang Pembelajaran secara Daring dan Bekerja dari Rumah dalam Rangka Pencegahan Penyebaran Corona Virus Disease (COVID- 19), pembelajaran di berbagai jenjang pendidikan yang semula dilakukan secara tatap muka berganti menjadi pembelajaran secara daring (dalam jaringan) atau pembelajaran yang dilakukan secara online. Pembelajaran daring menekankan pada proses belajar dengan menggunakan teknologi internet untuk mengirimkan berbagai hal yang dapat meningkatkan pengetahuan serta keterampilan (Elyas, 2018). Selain tantangan kondisi tersebut, tantangan lain yang tak kalah penting adalah mempersiapkan generasi muda agar memiliki kompetensi abad ke-21. Kompetensi abad ke-21 merupakan kompetensi utama yang harus dimiliki peserta didik agar mampu berkiprah dalam kehidupan nyata pada abad 21. Menurut Kemendikbud (2017), kompetensi keterampilan abad 21 yang harus dimiliki peserta didik atau yang biasa dikenal dengan 4C yaitu: kreativitas dan inovasi (creativity and innovation), berpikir kritis dan pemecahan masalah (critical thinking and problem solving), komunikasi (communication), dan kolaborasi (collaboration).

IPA merupakan salah satu muatan pelajaran pokok yang diajarkan di tingkat sekolah dasar. Menurut Wisudawati \& Sulistyowati (2014: 22) IPA mempelajari fenomena alam yang aktual (factual), berupa kenyataan (reality) atau kejadian (events), dan hubungan sebab akibatnya. Ardianti (2015: 2) menambahkan bahwa pembelajaran IPA berkaitan dengan cara mencari tahu tentang alam secara sistematis, sehingga IPA bukan hanya penguasaan kumpulan pengetahuan yang berupa fakta, konsep, atau prinsip saja tetapi juga merupakan proses penemuan. Pada pembelajaran temuan mengharuskan siswa terlibat dalam proses penemuan fakta dan konsep sehingga akan menimbulkan pembelajaran bermakna.

Pembelajaran seharusnya berpusat pada siswa dan guru harus bisa merancang suatu pembelajaran yang menekankan aktivitas siswa secara penuh dalam menggali pengetahuannya dengan melakukan percobaan dan mengembangkan potensi yang dimilikinya dalam memecahkan suatu permasalahan sehingga siswa bisa memahami materi pelajaran dengan baik. Pemahaman siswa terhadap materi yang dipelajari akan berdampak pada hasil belajar siswa itu sendiri. Semakin siswa memahami materi yang dipelajari, maka hasil belajarnya juga akan semakin meningkat (Candrayani, dkk, 2016). Dengan demikian pembelajaran berpusat pada peserta didik (student center) dengan guru sebagai fasilitator dalam proses pembelajaran.

Namun, berdasarkan hasil observasi dan wawancara guru kelas V SDN 1 Karangsari yang dilakukan peneliti diperoleh beberapa fakta antara lain: (1) terbatasnya perangkat teknologi untuk pembelajaran. Pembelajaran yang dilakukan secara daring membutuhkan berbagai piranti yang dapat menunjang tercapainya tujuan pembelajaran, namun peserta didik kelas V SDN 1 Karangsari memiliki keterbatasan perangkat seperti handphone/ laptop dan akses internet, (2) penugasan pada muatan IPA belum maksimal, hanya terbatas pada penugasan soal di LKS sehingga peserta didik lama kelamaan mengalami kebosanan, (3) kegiatan tanya jawab antara guru dan peserta didik berjalan kurang maksimal, (4) pembelajaran kurang menantang siswa untuk menyelesaikan masalah atau menemukan konsep dari materi yang diajarkan. Kurang maksimalnya pembelajaran berdampak pada nilai $\mathrm{PH}$ kelas V SDN 1 Karangsari pada muatan IPA yang tergolong kurang. Presentase ketuntasan sebesar $42,10 \%$ atau 8 peserta didik yang tuntas dari 19 peserta didik dengan KKM 70.

Berdasarkan kondisi tersebut, peneliti melakukan upaya perbaikan dengan menerapkan model pembelajaran inkuiri terbimbing untuk meningkatkan hasil belajar IPA peserta didik. Sanjaya berpendapat bahwa, "Inkuiri adalah rangkaian kegiatan pembelajaran yang menekankan pada proses berpikir secara kritis dan analitis untuk 
mencari dan menemukan sendiri jawaban dari suatu permasalahan yang dipertanyakan" (2012: 196). Peserta didik dituntut untuk berpikir kritis dan analitis untuk memecahkan masalah sehingga peserta didik tidak hanya mendapatkan pengetahuan secara verbal dari guru, namun peserta didik secara aktif menemukan sendiri makna dan substansi dari materi yang diajarkan sehingga pembelajaran lebih bermakna bagi peserta didik. Koksal \& Giray (2014: 67) menyatakan bahwa pada pada pelaksanaan inkuiri terbimbing diperlukan bimbingan guru saat pembelajaran. Guru mengajukan pertanyaan yang bermakna bagi siswa dan memberikan petunjuk agar penyelidikan tetap mengarah pada tujuan pembelajaran. Pengajuan pertanyaan yang tepat oleh guru akan merangsang kreativitas siswa dan membantu mereka dalam "menemukan" pengetahuan baru tersebut. Model pembelajaran inkuiri terbimbing memang memerlukan waktu yang relatif banyak dalam pelaksanaanya, akan tetapi hasil belajar yang dicapai tentunya sebanding dengan waktu yang digunakan. Pengetahuan baru akan melekat lebih lama apabila siswa dilibatkan secara langsung dalam proses belajar mengajar (Yudhanegara, 2019:213).

Bell, et.al (2013: 353-356) yang membagi proses inkuiri menjadi sembilan tahap, yakni: (1) orienting, (2) asking question, (3) hypothesis generation, (4) planning, (5) investigation, (6) analysis and interpretation, (7) conclusion), (8) communication, (9) prediction.

Keefektifan model pembelajaran inkuiri terbimbing telah dibuktikan oleh penelitian yang dilakukan Azka, dkk (2020: 173) yang menyimpulkan bahwa model inkuiri terbimbing berbantuan media roda pintar dapat meningkatkan hasil belajar siswa ranah pengetahuan, sikap dan keterampilan pada muatan pelajaran Bahasa Indonesia.

Berdasarkan uraian diatas, rumusan masalah penelitian ini yaitu bagaimana penerapan model pembelajaran inkuiri terbimbing untuk meningkatkan hasil belajar IPA pada peserta didik kelas V SDN 1 Karangsari tahun ajaran 2020/2021?

Tujuan dari penelitian ini yaitu untuk meningkatkan hasil belajar IPA pada peserta didik kelas V SDN 1 Karangsari tahun ajaran 2020/ 2021 melalui penerapan model pembelajaran inkuiri terbimbing.

\section{METODE}

Penelitian ini merupakan penelitian tindakan kelas dengan menerapkan model pembelajaran inkuiri terbimbing. Penelitian ini dilaksanakan pada peserta didik kelas $\mathrm{V}$ SDN 1 Karangsari yang berjumlah 19 selama II siklus. Siklus I dilaksanakan pada 25 Maret dan 1 April 2021 sementara siklus II pada 15 dan 17 April 2021. Teknik pengumpulan data menggunakan observasi, wawancara, dokumentasi, dan tes. Jenis data penelitian ini adalah data kualitatif berupa penerapan model pembelajaran inkuir terbimbing dan data kuantitatif berupa hasil belajar IPA. Uji validitas data menggunakan triangulasi teknik dan sumber. Analisis data meliputi reduksi data, penyajian data, dan kesimpulan sesuai model analisis data (Sugiyono, 2015: 338-345).

\section{HASIL DAN PEMBAHASAN}

Pada siklus I pembelajaran dilaksanakan selama dua pertemuan. Pertemuan pertama membahas tentang sifat benda padat, sementara pertemuan kedua membahas peristiwa membeku dan mencair. Berikut ini hasil belajar peserta didik pada siklus I yang dapat dilihat pada tabel berikut.

Tabel 1. Hasil Belajar Peserta Didik pada Siklus I

\begin{tabular}{|c|c|c|c|}
\hline \multirow{2}{*}{ Hasil Belajar Peserta didik } & \multicolumn{2}{|c|}{ Pertemuan } & \multirow{2}{*}{ Rata-Rata } \\
\hline & 1 & 2 & \\
\hline Rata-Rata & 67,47 & 71,10 & 69,28 \\
\hline
\end{tabular}




\begin{tabular}{lll}
\hline Peserta didik Belum Tuntas & 9 & 6 \\
Persentase Peserta didik Tuntas & $52,63 \%$ & $68,42 \%$ \\
Persentase Peserta didik Belum & $47,36 \%$ & $31,57 \%$ \\
Tuntas & Meningkat & Meningkat \\
\hline
\end{tabular}

Berdasarkan tabel di atas, hasil belajar peserta didik pada pertemuan 1 dan 2 mengalami peningkatan. Pada pertemuan pertama hasil belajar peserta didik memperoleh nilai rata-rata 67,5 dengan persentase peserta didik tuntas $52,63 \%$ atau 10 peserta didik yang sudah memenuhi KKM. Sedangkan $47,36 \%$ atau 9 peserta didik lainnya belum memenuhi KKM. Pada pertemuan kedua perolehan nilai rata-rata hasil belajar peserta didik pada yaitu 69,82 dengan persentase $68,42 \%$ atau 13 peserta didik sudah memenuhi KKM, sedangkan $31,57 \%$ atau 6 peserta didik lainnya belum memenuhi KKM. Diperlukan adanya perbaikan pada siklus berikutnya agar hasil belajar peserta didik mencapai KKM yaitu $\geq 70$.

Siklus II terdiri dari dua pertemuan, pertemuan pertama membahas peristiwa menguap dan mengembun, sedangkan pertemuan kedua membahas peristiwa menyublim. Hasil belajar pada siklus II dapat dilihat pada tabel berikut.

Tabel 2. Hasil Belajar Peserta Didik pada Siklus II

\begin{tabular}{lccc}
\hline \multirow{2}{*}{ Hasil Belajar Peserta didik } & \multicolumn{2}{c}{ Pertemuan } & \multirow{2}{*}{ Rata-Rata } \\
\cline { 2 - 3 } & $\mathbf{1}$ & $\mathbf{2}$ & \multirow{2}{*}{76,55} \\
Rata-Rata & 75,52 & 77,57 & \\
Peserta didik Tuntas & 15 & 17 & \\
Peserta didik Belum Tuntas & 4 & 2 & \\
Persentase Peserta didik Tuntas & $78,94 \%$ & $89,47 \%$ & \\
Persentase Peserta didik Belum & $21,05 \%$ & $10,52 \%$ & \\
Tuntas & Meningkat & Meningkat & \\
Keterangan & & & \\
\hline
\end{tabular}

Berdasarkan tabel di atas, hasil belajar peserta didik pada siklus II pertemuan 1 dan 2 mengalami peningkatan. Pada pertemuan pertama hasil belajar peserta didik memperoleh nilai rata-rata 75,52 dengan persentase peserta didik tuntas $78,94 \%$ atau 15 peserta didik yang sudah memenuhi KKM. Sedangkan $21,05 \%$ atau 4 peserta didik lainnya belum memenuhi KKM. Pada pertemuan kedua perolehan nilai rata-rata hasil belajar peserta didik pada yaitu 77,57 dengan persentase $89,47 \%$ atau 17 peserta didik sudah memenuhi KKM, sedangkan 10,52 \% atau 2 peserta didik lainnya belum memenuhi KKM. Berdasarkan hasil analisis antar pertemuan pada siklus II dapat disimpulkan bahwa hasil belajar pada siklus II mengalami peningkatan pada setiap pertemuan dan sudah mencapai indikator kinerja penelitian yaitu $80 \%$.

Hasil penelitian menunjukkan bahwa terjadi peningkatan hasil belajar IPA tentang perubahan wujud pada peserta didik kelas V. Peningkatan ketuntasan hasil belajar tersebut sesuai dengan penelitian yang dilakukan Kusumah, dkk (2020) yang menunjukkan bahwa penerapan inkuiri dapat meningkatkan hasil belajar peserta didik kelas IV tentang penggolongan hewan. Model pembelajaran inkuiri terbimbing dapat meningkatkan pembelajaran IPA yang berupa hasil belajar. Adanya peningkatan hasil belajar peserta didik kelas $\mathrm{V}$ pada muatan IPA membuktikan bahwa model pembelajaran inkuiri terbimbing dapat membantu peserta didik membangkitkan pemahaman isi pelajaran, menumbuhkan keterlibatan dan partisipasi peserta didik, dan membantu peserta didik mempelajari ketrampilan komunikasi dan proses berpikir (Trianto, 2014: 156). Hal ini sejalan dengan pendapat Olibie \& Kate (2014: 337) yang 
berpendapat bahwa di dalam inkuiri terbimbing siswa memiliki kebebasan untuk berpartisipasi, menyelidiki, dan berperan utama dalam pembelajaran.

Pengetahuan yang didapat siswa ketika belajar inkuiri adalah pengetahuan yang bermakna dan bersifat jangka panjang karena hasil konstruksi pengetahuan yang didapat selama pembelajaran dengan pengetahuan awal. Dalam model pembelajaran inkuiri terbimbing siswa secara aktif dalam proses pembelajaran yaitu mulai dari perencanaan, pelaksanaan, sampai proses evaluasi. Dengan menerapkan pembelajaran berbasis inkuiri akan memacu keingintahuan siswa dalam menemukan hal-hal yang ingin diketahui siswa (Udiani, 2017). Dengan bimbingan guru dan LKPD yang telah disiapkan, peserta didik belajar menemukan esensi dari suatu materi melalui pengalaman langsung seperti percobaan dan penemuan yang memberikan pengalaman bermakna bagi peserta didik. Peran guru yang optimal sangat dibutuhkan saat pelaksanaan pembelajaran dengan inkuiri terbimbing. Guru diharapkan dapat mengarahkan siswa untuk merumuskan masalah, pengumpulan dan analisis data, sekaligus membuat hipotesis secara mandiri, membuat kesimpulan dari pengamatan yang dilakukannya (Niana, et al, 2016: 616).

\section{SIMPULAN}

Penerapan model pembelajaran inkuiri terbimbing dapat meningkatkan hasil belajar IPA tentang perubahan wujud benda pada peserta didik kelas V SDN 1 Karangsari tahun ajaran 2020/2021. Hal tersebut dapat dilihat dari ketuntasan belajar peserta didik dilihat dari hasil belajar peserta didik. Persenta 2se ketuntasan peserta didik pada siklus I meningkat menjadi $60,52 \%$ dan siklus II menjadi $84,21 \%$.

Berdasarkan simpulan di atas, peneliti memiliki beberapa saran yaitu guru meningkatkan ketrampilan membimbing diskusi kelompok dan kemampuan memotivasi dalam penerapan model pembelajaran inkuiri terbimbing, sekolah memfasilitasi guru dalam penerapan model pembelajaran inkuiri terbimbing, dan keberhasilan penelitian ini dapat digunakan sebagai dasar pengembangan penelitian yang menerapkan model pembelajaran inkuiri terbimbing untuk meningkatkan hasil belajar IPA.

\section{DAFTAR PUSTAKA}

Ardianti, S.D. (2015). Pengaruh Modul Tematik Inquiry-Discovery Terhadap Hasil Belajar Siswa Materi Metabolisme Pembentuk Bioenergi. Refleksi Edukatika: Jurnal IImiah Pendidikan, 5(2):1-6.

Azka, dkk. (2020). Peningkatan Hasil Belajar Siswa melalui Model Inkuiri Terbimbing Berbantuan Media Roda Pintar. Journal for Lesson and Learning Studies, 2 (3). 163.

Bell, et al. (2010). Collaborative Inquiry Learning: Models, Tools, and Challenges. International Journal of Science Education, 32 (3), 349-377.

Candrayani, P.A. (2017). Penerapan Model Pembelajaran Inkuiri Terbimbing untuk Meningkatkan Aktivitas dan Hasil Belajar IPA Siswa. E-Journal PGSD Universitas Pendidikan Ganesha, 4 (1), 4.

Kemendikbud. (2017). Materi Umum SD. Jakarta: Direktorat Jenderal Pendidikan Dasar dan Menengah.

Koksal, G. A. \& Giray, B. (2014). The Effect of Guided-Inquiry Instruction on 6th Grade Turkish Students' Achievement, Science Process Skills, and Attitudes Toward Science. International Journal of Science Education, 36 (1), 66-78.

Kusumah, dkk. (2020). Penerapan Metode Inquiry Sebagai Usaha untuk Meningkatkan Hasil Belajar IPA pada Materi Penggolongan Hewan di Kelas IV SD Seluma. Jurnal Pendidikan Matematika dan IPA, 11(1). 142-153.

Niana, et al. (2016). The Application of Guided Inquiry Model On Physic Learning To Improve Scientific Attitude And Students' Analysis Ability. Proceeding The 2nd 
International Conference On Teacher Training and Education Sebelas Maret University, 2 (1). 616.

Olibie, E. I. \& Kate O, E. Ability and Location Differences in the Effects of Guided Inquiry on Nigerian Students' Achievement in Social Studies Curriculum. Journal of Education and Human Development, 3 (4), 335-344.

Sanjaya, W. (2012). Strategi Pembelajaran Berorientasi Standar Proses Pendidikan. Jakarta: Kencana Prenada Media Group.

Sugiyono. (2015). Metode Penelitian Tindakan Pendekatan Kuantitatif, Kualitatif, dan $R$ \& $D$. Bandung: Alfabeta.

Trianto. (2014). Mendesain Model Pembelajaran Inovatif, Progresif, dan Kontekstual: Konsep, Landasan, dan Implementasinya Pada Kurikulum. Jakarta: Prenadamedia Group.

Udiani, N. K, dkk. (2017). Pengaruh Model Pembelajaran Inkuiri Terbimbing Terhadap Hasil Belajar IPA dengan Mengendalikan Keterampilan Proses Sains Siswa Kelas IV SD No. 7 Benoa Kecamatan Kuta Selatan Kabupaten Badung. EJournal Program Pascasarjana Universitas Pendidikan Ganesha, 7 (1).

Wisudawati, A.W. dan Sulistyowati, E. (2014). Metodologi Pembelajaran IPA. Jakarta: Bumi Aksara.

Yudhanegara, dkk. (2019). Penerapan Model Inkuiri Terbimbing untuk Meningkatkan Hasil Belajar Siswa dalam Pembelajaran IPS. Jurnal Cakrawala Pendas, 5 (2). 210. 